\title{
Are Lack of Self-Confidence and Low Self-Esteem in Anxiety and Depression Partly Responsible for the Inability to Reproduce Knowledge, Skills and Abilities?
}

\author{
Dr. Josef Wacker* \\ Clinical Psychologist, Practice for Psychotherapy, Germany
}

Submission: March 03, 2021; Published: April 16, 2021

*Corresponding author: Dr. Josef Wacker, Practice for Psychotherapy, Clinical Psychologist, Certified psychologist and psychological psychotherapist, Children \& Teenagers Psychotherapist and Behavioural Therapist, Arnsberg, Germany

Summary

The empirical studies on the differences in remembering or delayed remembering between knowledge of already learned skills and existing inabilities showed that the number of remembered skills differs significantly between the inconspicuous and the anxious and depressive, but not between the anxious and the depressive. The groups did not differ in the verbalization of inabilities. However, profession and school education do have an influence on the persons' ability to remember. There are also significant differences in the duration of therapy between groups without therapy or with short therapy duration ( $>25$ sessions) and groups with 60 or more therapy sessions. If, during the therapeutic process, there is a de-normalization, the targeted removal of self-evident facts and the positive re-evaluation of these forgotten learning contents and knowledge about them, the verbal reproducibility of knowledge about already learned skills increases. The moment these skills are once again attributed an importance, when they are consciously practiced, shown and emotionally reacted to, they remain stored as positive memories for a longer time and protected against new forgetting. This awareness of having learned a lot and being able to do a lot leads to a significant increase in personal self-confidence and consequently to a better self-esteem.

Keywords: Skills; self-confidence; Self-esteem; Forgetting; Memory; Remembering.

\section{Introduction}

In the course of my 40 years of work as a psychological psychotherapist in private practice and as a psychotherapist for children and adolescents, I have repeatedly found that patients suffering from anxiety and/or depression have not been able to give spontaneous answers to the questions I have asked about their abilities and skills. Only after a certain time were a few, few abilities named. Mostly these abilities were in the area of the special, the rather extraordinary, less in the everyday. To the question: „What can't you do?" was answered much faster and also more incapacities were named. The question why this is so was always answered for almost all test persons by saying that the basic abilities such as: „walking, reading and writing, or calculating, or brushing one's own teeth were considered to be something completely normal, something taken for granted that everyone can do; after all, it is nothing special.

\section{Theoretical Background}

Skills (knowledge \& actions) serve to build self-confidence. The positive evaluation of these abilities is a prerequisite for the development of self-esteem. For him self-esteem represents the positive evaluation of the self: „self- esteem may be defined as the positivity of the person`s evaluations of self" [1]. The development of self-esteem is dependent on the social interactions in which the individual is seen and evaluated. The classics of the theories of self [2-4] emphasized the dependence of self-worth on the generalized other or on looking glass-self, on the consideration and evaluation of fellow humans. Through the self-experienced feedback of his fellow human beings, the person experiences affection, recognition and appreciation. As a result of the self-decision that I am the one who is praised, that it is my abilities that are positively evaluated, self-esteem is further developed and stabilized $[5,6]$. 
Some authors assume that self-esteem can also be structured hierarchically and divided into different aspects [7-9]. Self-esteem is the sum of subjective feelings about the value of oneself. It is thus also a term for the emotional and cognitive evaluations of an individual's behavior, about his or her conception of himself or herself, his or her nature, character (self-image) and worldview [10]. During the learning process, during the acquisition of skills, the acting person is aware of them. He shows what he can do. The frequent use and practice lead to increased security (ability). Admiration and recognition as emotional feedback increases self-esteem. From a behavioral theory perspective, this positive feedback represents a positive reinforce-ment, which, as has been scientifically proven, increases the probability of this behavior occurring [11] (Figure 1).

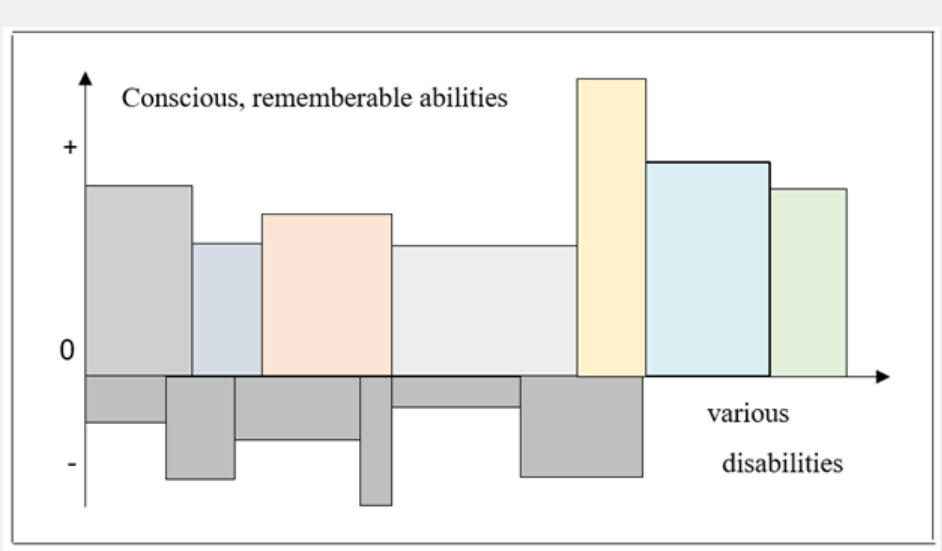

Figure 1: Figure representing Conscious, rememberable abilities of the person.

According to the principle of extinction [11], or the law of effect [12], behaviors are eliminated when they are no longer amplified or have no effect. The normalization of one's own skills or the explanation of one's own abilities as something self-evident could thus work as an extinction, since these skills can no longer be admired and find no more recognition. As a result, they are no longer important, which leads to a reduction of these abilities in consciousness (Figure 2).

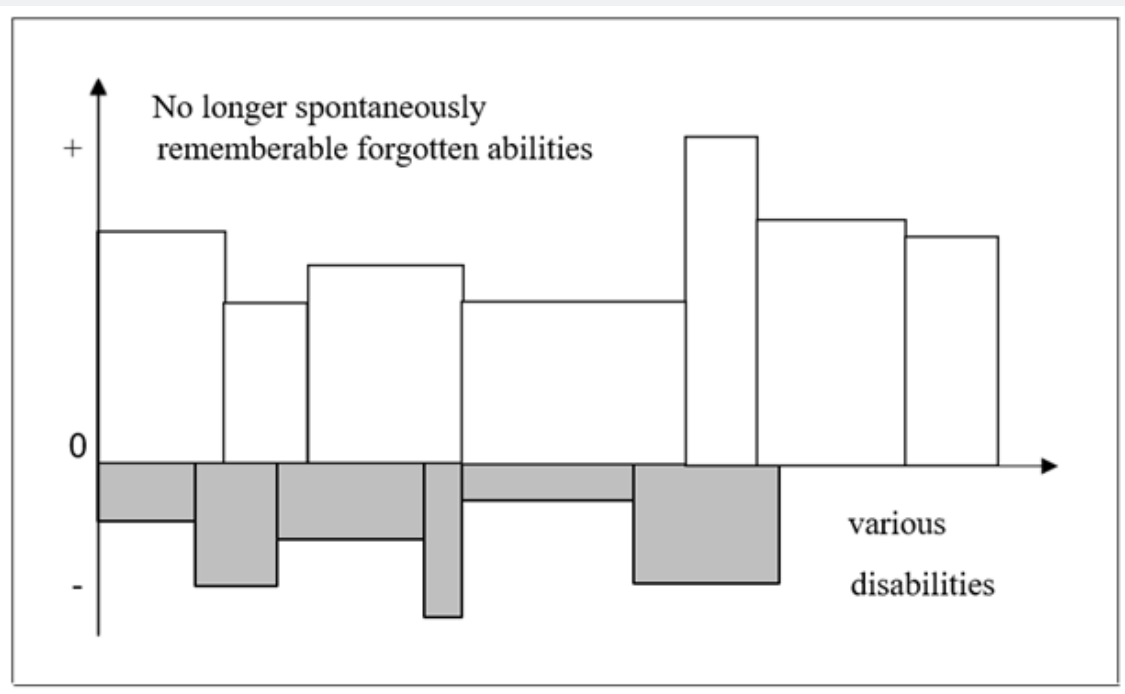

Figure 2: Figure representing no longer spontaneously rememberable forgotten abilities of the person.

Even children are confronted with this normalization of acquired skills: „Don't imagine things, everyone else can do that too! Even the skills learned under pain (walking) are, over time, presented as something quite natural. However, not only the acquired skills and abilities are declared to be more or less unimportant, but also this knowledge about them, which leads to the omission of reinforcement units and thus reduces the actuality in the memory and thus the once learned is forgotten 
and prevents spontaneous verbalization and makes remembering at least more difficult. The time factor also plays an important role in forgetting. Long stored memories turn yellow, blur with time, like old pictures (photos) to make room for new ones. Memory is the ability to store experiences in the sense of knowledge as information, similar to a hard disk in a computer. Memory, whether short or long term, processes these data in the form of memories.
The distinction between procedural, declarative, emotional, implicit and semantic memory is made here. Depending on the type of memory, whether it is about events, behavior and skills, or emotional experiences, similar to the classification of knowledge. A good overview is provided by the following model adjustment [13]. There is also no central place of storage, but different areas within the brain (Figure 3).

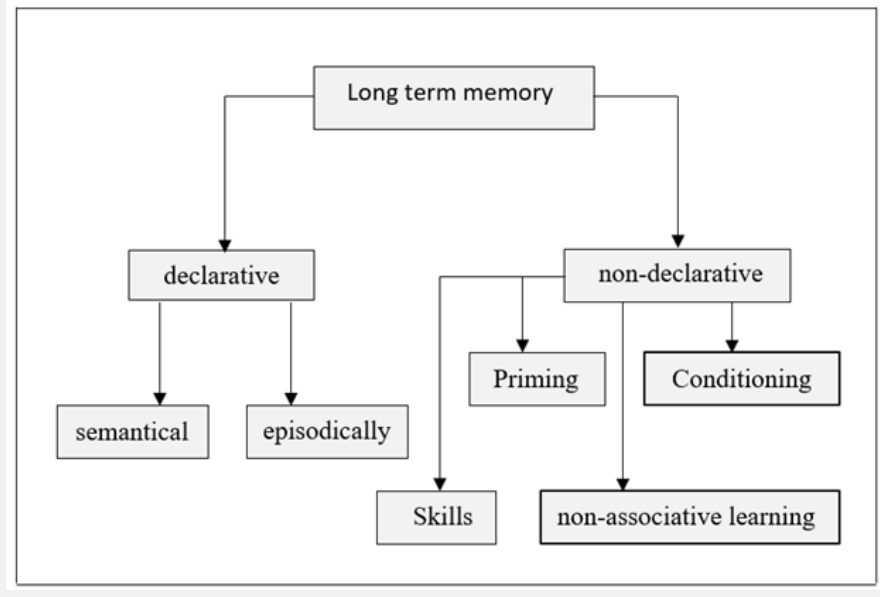

Figure 3: The mechanism of neural networks (synaptic transmission of excitation) within the brain.

The mechanism of neural networks (synaptic transmission of excitation) within the brain involved in forgetting is similar to that of learning. Significantly involved brain regions are the hypocampus and the limbic system with amygdala.

Some Scientists $[14,15]$ assumed in their theories that forgetting is the inability to reproduce or re-recognize learned knowledge and skills (see forgetting curve, trace decay theory, interference theory). Social scientists assume that forgetting is a process of cleansing and purifying, of separating irrelevant or superfluous things [16,17]. Their theories became known as forgetting as the basis for new opportunities and identity, forgetting through an excess of stored information. N. Luhmann sums up in his systems theory: „The main function of memory is thus forgetting, preventing the system from blocking itself by clotting the results of previous observations [18]. This statement finds its confirmation in the latest scientific research. It has been found that our brain not only forgets, but falsifies experiences and memories or even turns them into the opposite. Why is this so? There are many reasons. A very pragmatic necessary cause is the fact that too much information burdens the capacity of the memory and therefore new experiences, skills can be stored less. „Forgetting is absolutely essential, especially for memory. But it is simply not appreciated" [19]. Our existence consists in a continuous modification of the circumstances of life. In order to be able to always react optimally to this, it is of central importance that our brain is able to learn skills and forgets the knowledge about it in order to absorb and integrate new things. Thus forgetting is not a cognitive error, but an active cognitive process in which the important is separated from the unimportant.

Psychoanalysts assume that there is an unconscious strategy of forgetting negative, stressful past experiences (theory of motivate/targeted forgetting through conscious and/or unconscious repression) in order to increase the capacity for upcoming problem-solving strategies. As mentioned before, learning theorists speak of deletion. The following investigation is primarily concerned with forgetting knowledge of stored skills (ability) and making this knowledge conscious again from nondeclarative memory.

\section{Questions}

i. Do lack of self-confidence and low self-esteem as symptoms of depression and anxiety have a memory-blocking effect?

ii. Are abilities remembered less and more slowly than inabilities?

iii. Does de-normalization (awareness of forgotten or repressed learning content) lead to a faster re-verbalization of previously learned skills?

\section{Empirical investigation}

i. The examination clientele: With the help of the standardized clinical test procedures BDI [20] and BAI [21], the observable symptomatology (classification according to the 
criteria of DSM-V; [22] ICD 11[23]) and the clinical picture, 60 persons were examined with regard to the disturbance pictures: depressions and anxieties and divided into three different groups according to these criteria (independent variables)
a. Group with inconspicuous
b. Group with fears
c. Group of depressions

The parameters age, gender, education and occupation were also determined and used as independent variables. The dependent variables were determined with the help of specific questions such as: „Tell me what they can do, how much ability they have? Or 2nd question: „How many incapacities do you have or what you cannot do? The subjects had 60 seconds for each question. A stopwatch was used to measure the time that elapsed from the respective question to the beginning of the first entries. In addition, the respective number of entries (abilities and disabilities) was recorded. In addition to this quantitative recording, the quality of the abilities/inabilities (simple extraordinary) was also noted. These data were transferred into an evaluation and data sheet created for this purpose.

Using this evaluation sheet, the clientele to be examined was divided into the different groups, independent and dependent variables were determined and entered as empirical data into IBM's computer program SPSS 25.

Illustration: Evaluation and data sheet for independent and dependent variables (Figure 4).

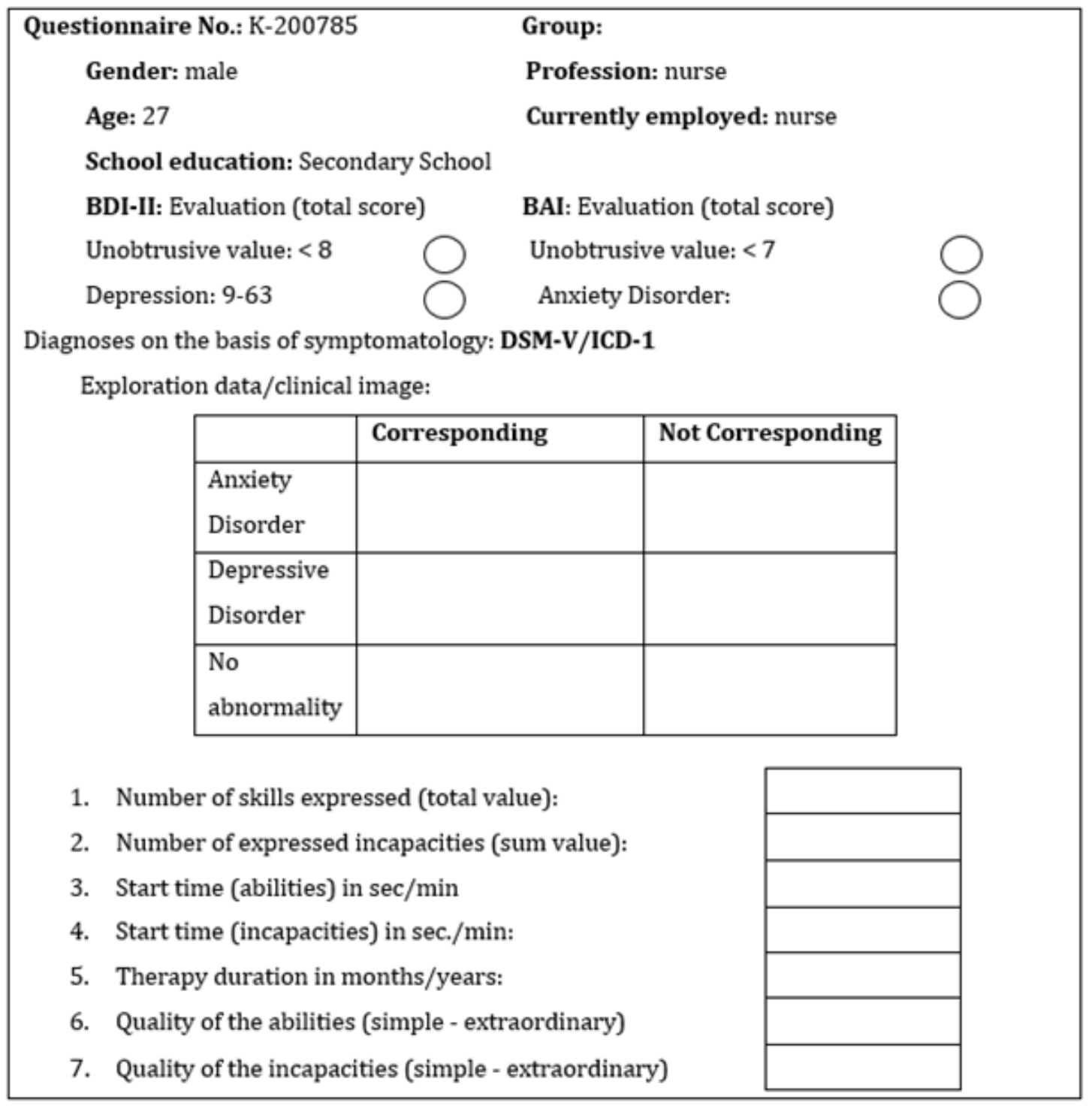

Figure 4: Illustration of evaluation and data sheet for independent and dependent variables. 


\section{Psychology and Behavioral Science International Journal}

In order to be able to guarantee data analysis and hypothesis testing that meets the criteria of classical test theory, the corresponding statistical calculations are performed depending on the scale level available.

Distribution of the total sample in the form of bar charts: (Graphs 1-4)

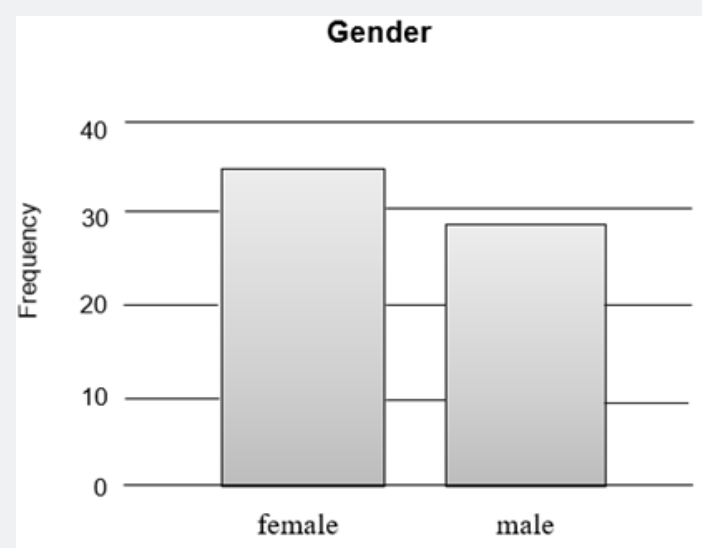

Graph 1: Gender distribution/frequencies.

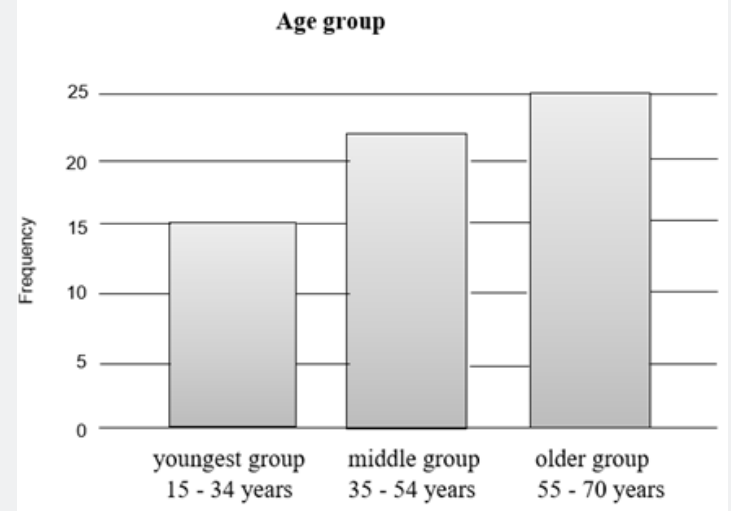

Graph 2: Age distribution/frequencies.

\section{School Education}

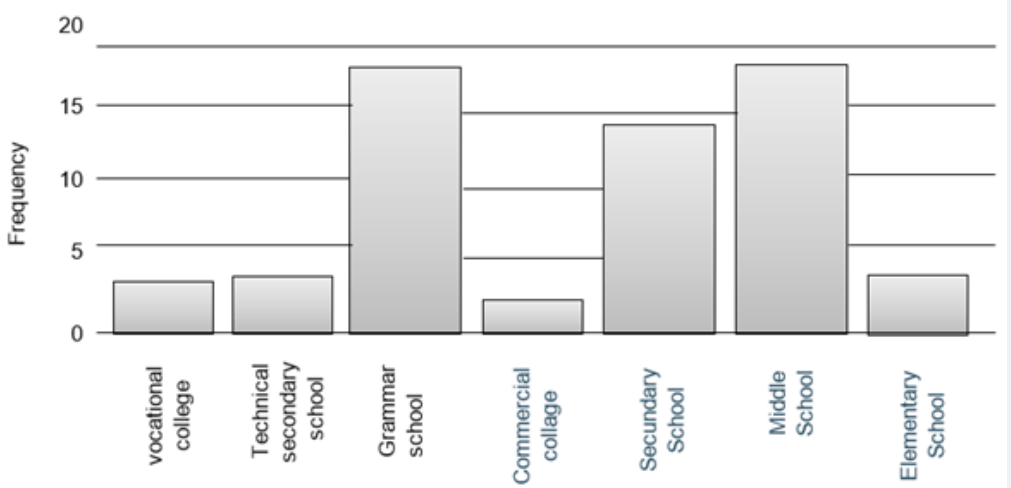

Graph 3: Distribution/frequencies of school education. 


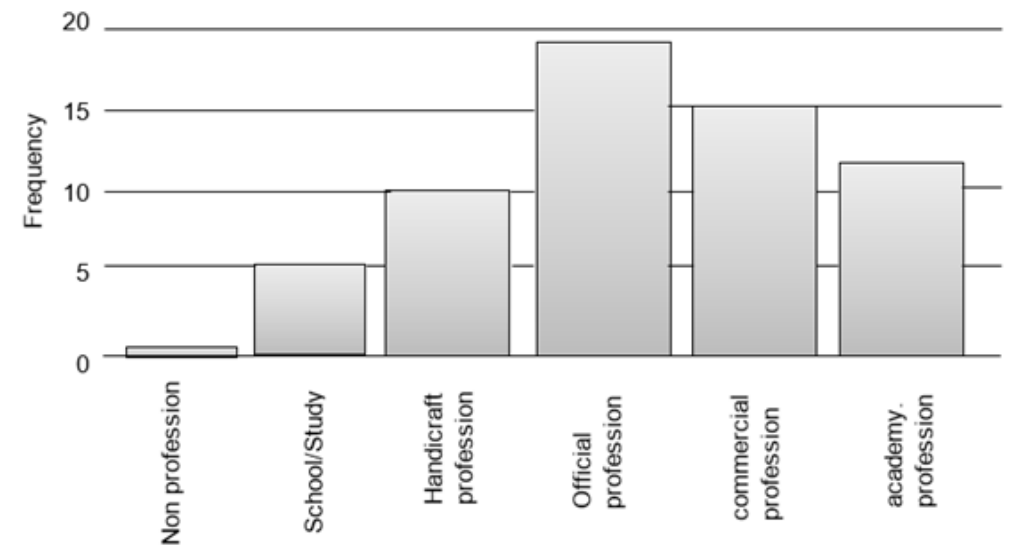

Graph 4: Distribution/frequencies of the professions.

\section{Distribution within the different groups}

It was examined beforehand whether the personal data of the Vpn (gender, age, education and occupation) are randomly distributed within the groups and whether alternative explanations for the hypothesis check can be excluded. The distributions were summarized in cross tables and checked for significant correlations with the Chi-square procedure.

i. Cross table: Group * Gender (Tables 1 and 2).

Result: There are no sig. connections between school education and group-affiliation.

Table 1: Cross table: Group * Gender

\section{ii. $\quad$ Cross table: Group* Agegroup (Tables 3 and 4).}

Result: There is also no significant correlation between the age of the subjects and group membership (standardized residual is less than 2 , significance is $>0.05$ ).

\section{iii. Cross table: Group * School group (Tables 5 and 6).}

Result: There are no sig. connections between school education and group-affiliation.

iv. Cross table: Group * Professional Group (Tables 7 and 8).

\begin{tabular}{|c|c|c|c|c|c|}
\hline & & & \multicolumn{2}{|c|}{ Gender } & \multirow{2}{*}{ Total } \\
\hline & & & Female & Male & \\
\hline \multirow{9}{*}{ Group } & \multirow{3}{*}{ Unobtrusive } & Number & 9 & 12 & 21 \\
\hline & & Expected number & 11,9 & 9,1 & 21,0 \\
\hline & & Standardized residual &,- 8 & 1,0 & \\
\hline & \multirow{3}{*}{ Anxious } & Number & 14 & 8 & 22 \\
\hline & & Expected number & 12,5 & 9,5 & 22,0 \\
\hline & & Standardized residual & 4 &,- 5 & \\
\hline & \multirow{3}{*}{ Depressive } & Number & 11 & 6 & 17 \\
\hline & & Expected number & 9,6 & 7,4 & 17,0 \\
\hline & & Standardized residual & 4 &,- 5 & \\
\hline \multirow{2}{*}{\multicolumn{2}{|c|}{ Total }} & Number & 34 & 26 & 60 \\
\hline & & Expected number & 34,0 & 26,0 & 60,0 \\
\hline
\end{tabular}




\section{Psychology and Behavioral Science International Journal}

Table 2: Chi-square tests.

\begin{tabular}{|c|c|c|c|}
\hline & Value & df & $\begin{array}{c}\text { Asymptotic } \\
\text { significance } \\
\text { (two-sided-) }\end{array}$ \\
\hline Chi-square after Pearson & $2,514^{\mathrm{a}}$ & 2 &, 285 \\
\hline Likelihood quotient & 2,510 & 2 &, 285 \\
\hline Connection linear-with-linear & 1,932 & 1 &, 165 \\
\hline Number of valid cases & 60 & & \\
\hline
\end{tabular}

a 0 cells $(0.0 \%)$ have an expected frequency less than 5 , the minimum expected frequency is 7.37 .

Table 3: Cross table: group* Agegroup.

\begin{tabular}{|c|c|c|c|c|c|c|}
\hline & & & \multicolumn{3}{|c|}{ Agegroup } & \multirow[b]{2}{*}{ Total } \\
\hline & & & $\begin{array}{c}\text { Youngest Group } \\
15 \text { bis } 34 \text { years }\end{array}$ & $\begin{array}{c}\text { Middle Group } \\
35 \text { bis } 54 \\
\text { years }\end{array}$ & $\begin{array}{c}\text { Older Group } \\
55 \text { bis } 75 \\
\text { years }\end{array}$ & \\
\hline \multirow{9}{*}{ Group } & \multirow{3}{*}{ Unobtrusive } & Number & 5 & 11 & 5 & 21 \\
\hline & & Expected number & 4,9 & 7,4 & 8,8 & 21,0 \\
\hline & & Standardized recidual & 0 & 1,3 & $-1,3$ & \\
\hline & \multirow{3}{*}{ Anxious } & Number & 6 & 6 & 10 & 22 \\
\hline & & Expected number & 5,1 & 7,7 & 9,2 & 22,0 \\
\hline & & Standardized recidual &, 4 &,- 6 & , 3 & \\
\hline & \multirow{3}{*}{ Depressive } & Number & 3 & 4 & 10 & 17 \\
\hline & & Expected number & 4,0 & 6,0 & 7,1 & 17,0 \\
\hline & & Standardized recidual &,- 5 &,- 8 & 1,1 & \\
\hline \multirow{2}{*}{\multicolumn{2}{|c|}{ Total }} & Number & 14 & 21 & 25 & 60 \\
\hline & & Expected number & 14,0 & 21,0 & 25,0 & 60,0 \\
\hline
\end{tabular}

Table 4: Chi-square tests.

\begin{tabular}{|c|c|c|c|}
\hline & Value & Asymptotic \\
significance \\
(two-sided-)
\end{tabular}

${ }^{\mathrm{a}} 0$ cells $(0.0 \%)$ have an expected frequency less than 5 , the minimum expected frequency is 5.00

Table 5: Cross table: Group * School group

\begin{tabular}{|c|c|c|c|c|c|c|}
\hline & & & \multicolumn{3}{|c|}{ Schoolgroup } & \multirow{2}{*}{ Total } \\
\hline & & & Main-/ Elementary & $\begin{array}{l}\text { Middle-/ Secund- } \\
\text { ary- / technical }\end{array}$ & $\begin{array}{l}\text { Vocational } \\
\text { College }\end{array}$ & \\
\hline \multirow{6}{*}{ Group } & \multirow{3}{*}{ Unobtrusive } & Number & 3 & 7 & 11 & 21 \\
\hline & & Expected number & 6,3 & 6,3 & 8,4 & 21,0 \\
\hline & & Standardized recidual & $-1,3$ & ,3 & ,9 & \\
\hline & \multirow{3}{*}{ Anxious } & Number & 9 & 7 & 6 & 2222 \\
\hline & & Expected number & 6,6 & 6,6 & 8,8 & 22,0 \\
\hline & & Standardized recidual & 9 & ,2 &,- 9 & \\
\hline
\end{tabular}




\section{Psychology and Behavioral Science International Journal}

\begin{tabular}{|c|c|c|c|c|c|c|}
\hline \multirow{3}{*}{ Group } & \multirow{3}{*}{ Depressive } & Number & 6 & 4 & 7 & 1717 \\
\hline & & Expected number & 5,1 & 5,1 & 6,8 & 17,0 \\
\hline & & Standardized recidual & 4 &,- 5 & 1 & \\
\hline \multirow{2}{*}{\multicolumn{2}{|c|}{ Total }} & Number & 18 & 18 & 24 & 6060 \\
\hline & & Expected number & 18,0 & 18,0 & 24,0 & 60,0 \\
\hline
\end{tabular}

Table 6: Chi-square tests

\begin{tabular}{|c|c|c|c|}
\hline & Value & df & $\begin{array}{c}\text { Asymptotic } \\
\text { significance } \\
\text { (two-sided-) }\end{array}$ \\
\hline Chi-square after Pearson & $4,801^{\mathrm{a}}$ & 4 &, 308 \\
\hline Likelihood quotient & 5,179 & 4 &, 269 \\
\hline Connection linear-with-linear & 1,645 & 1 &, 200 \\
\hline Number of valid cases & 60 & & \\
\hline
\end{tabular}

${ }^{a} 0$ cells $(0.0 \%)$ have an expected frequency less than 5 , the minimum expected frequency is 5.10 .

Table 7: Cross table: Group * Professional Group.

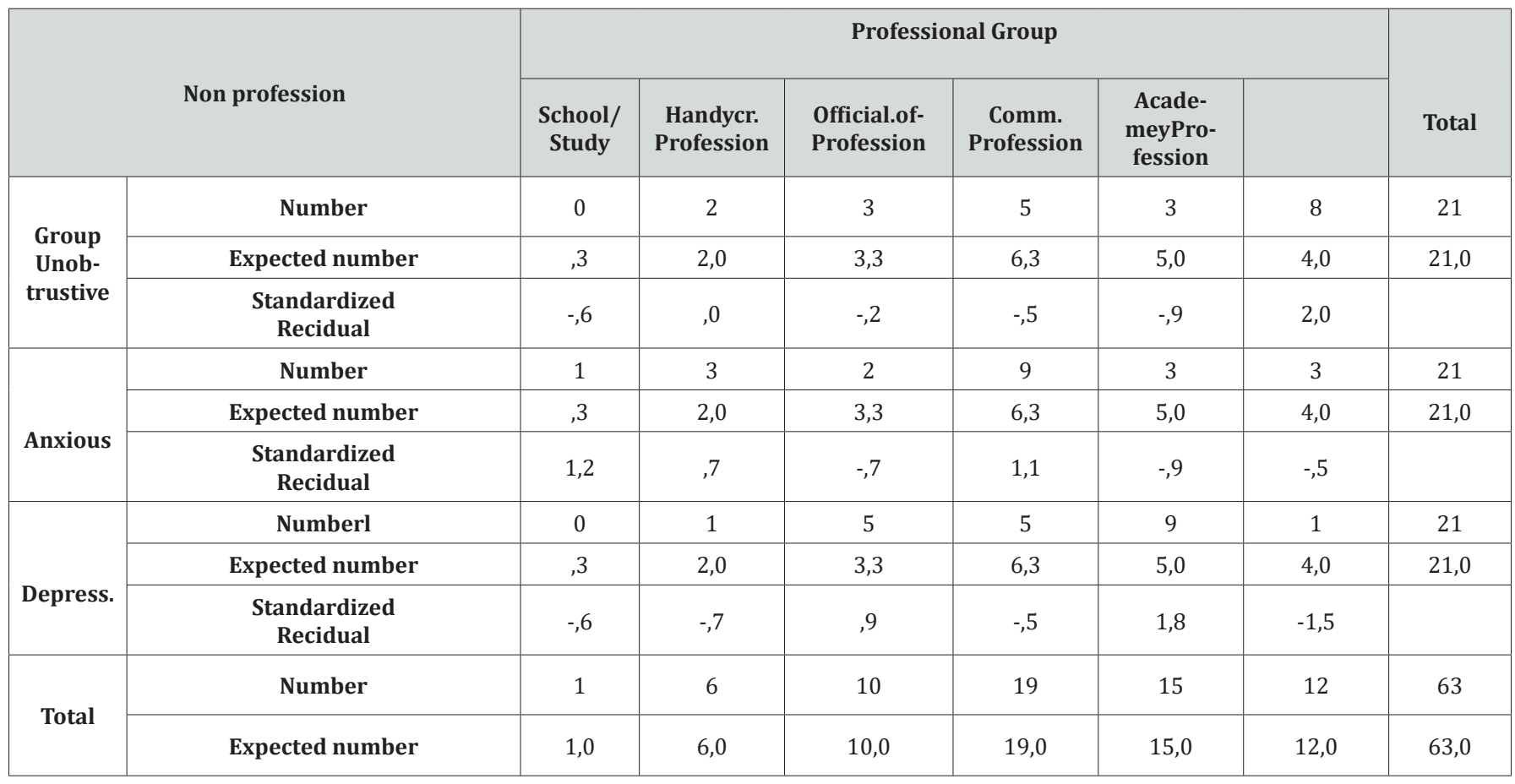

Table 8: Chi-square tests.

\begin{tabular}{|c|c|c|c|}
\hline & Value & df & $\begin{array}{c}\text { Asymptotic } \\
\text { signifikance (two-sided) }\end{array}$ \\
\hline Chi-square after Pearson & $17,384^{\mathrm{a}}$ & 10 &, 066 \\
\hline Likelihood quotient & 17,262 & 10 &, 069 \\
\hline Connection linear-with-linear &, 918 & 1 &, 338 \\
\hline Number of valid cases & 63 & & \\
\hline
\end{tabular}

a12 cells $(66,7 \%)$ have an expected frequency less than 5 , the minimum expected frequency is 33 .

${ }^{\mathrm{b}}$ The result is therefore rather problematic and has not so much weight or reliability. 
The following could be determined by checking with crosstables and Chi-square: The variables gender, age and school did not show a significant influence on the group under investigation.

For the independent variable Occupation, there is a tendency to show a significant difference between the members of an academic profession and the group of the inconspicuous (standardized residual of 2.0, indicates a significant deviation between the observed and expected frequencies). This means that an academic profession can provide some protection against an anxious and/or depressive disorder. This largely ensures that differences between groups that occur later are not due to the distribution of demographic variables.

\section{The statistical hypotheses}

In order to be able to carry out an exact scientifically recognized test of an empirical investigation, the questions formulated in the theoretical part of this work, based on observations in everyday therapeutic practice (see theoretical explanations), were formulated into the following explicit hypotheses, which were divided and named into a null hypothesis and individual alternative hypotheses.

The theoretically derived hypotheses were tested using the following inferential statistical procedures: Analysis of variance, multiple comparisons, crosstabs and chi-square and partial regression.

i. Ho: There is no statistically significant relationship between the independent variables (group) of dependent variables (number of skills/disabilities, quality of skills, duration to first mention or therapy duration).

ii. H1: There is a significant difference between the number of abilities/inabilities expressed within the different groups.

iii. H2: The number of verbalized abilities is higher among the inconspicuous than among the anxious and depressed.

iv. H3: There are significant differences in the quality (physical, intellectual or social) of verbalized abilities or inabilities within and between groups.

v. H4: With increasing duration of therapy and increased self-confidence combined with an improved self-esteem, previously learned abilities are also verbalized more quickly again.

Relationships between the number of skills and group membership

\section{i. Group statistics (Table 9) \\ ii. Single factorial ANOVA (Table 10)}

Table 9: Dependent variable: Number of skills

\begin{tabular}{|c|c|c|c|c|}
\hline Group & N & Mean value & Hourly deviation & Standard error of mean value \\
\hline Unobtrusive & 21 & 12.62 & 7.788 & 1.669 \\
\hline Anxious & 22 & 4,95 & 2,627 &, 560 \\
\hline Depressive & 17 & 4,35 & 2,172 &, 480 \\
\hline
\end{tabular}

Table 10: Single factorial ANOVA.

\begin{tabular}{|c|c|c|c|c|c|c|}
\hline \multicolumn{1}{|c|}{ Between the groups } & Square sum & df & Means of square & F & Signifikance \\
\hline \multirow{3}{*}{ Number of Skills } & Within the group & $1,395,789$ & 2 & 430,572 & 17,583 &, 000 \\
\cline { 2 - 7 } & Total & $2,256,933$ & 59 & 24,488 & \\
\cline { 2 - 7 } & & & & & & \\
\hline
\end{tabular}

First of all, it was examined whether there are differences in the naming of skills between the three groups. The varianceanalytical evaluation showed that there are significant differences between the investigated groups $(\mathrm{p}=.000)$. The hypothesis H 2 should therefore be retained. iii. Multiple comparisons (Table 11)

By calculating multiple comparisons (here: Scheffé) the variance-analytical result can be specified. The group of the anxious does not differ significantly from the group of the depressed, but both differ from the inconspicuous. 


\section{Psychology and Behavioral Science International Journal}

Table 11: Dependent variable: Number of skills, Scheffé-Procedure

\begin{tabular}{|c|c|c|c|c|c|c|}
\hline \multirow{2}{*}{ (I) Group } & \multirow{2}{*}{ (J) Group } & $\begin{array}{c}\text { Mean differen- } \\
\text { ce(I-J) }\end{array}$ & Std.-error & Signifikance & \multicolumn{2}{|c|}{ 95\%-Confidenceinterval } \\
\cline { 4 - 7 } & anxious & $7,665^{*}$ & 1,510 &, 000 & 3,87 & Upper Limit \\
\cline { 2 - 7 } Unobtrusive & depressive & $8,266^{*}$ & 1,614 &, 000 & 4,21 & 11,46 \\
\hline \multirow{2}{*}{ Anxious } & unobtrusive & $-7,665^{*}$ & 1,510 &, 000 & $-11,46$ & $-3,87$ \\
\cline { 2 - 7 } & depressive &, 602 & 1,598 &, 932 & $-3,41$ & $-12,32$ \\
\hline \multirow{2}{*}{ Depressive } & unobtrusive & $-8,266^{*}$ & 1,614 &, 000 & $-4,62$ & $-4,21$ \\
\cline { 2 - 7 } & anxious &,- 602 & 1,598 &, 932 & $-4,62$ & 3,41 \\
\hline
\end{tabular}

*The difference of the mean values is significance at the level 0.05 .

Relationships between the naming of inabilities and group membership

i. Group statistics (Table 12)

ii. Single factorial ANOVA (Table 13)

iii. Multiple comparisons (Table 14)

Table 12: Dependent variable: Number of incapacities

\begin{tabular}{|c|c|c|c|c|}
\hline Group & N & Mean value & Hourly deviation & $\begin{array}{c}\text { Standard error of mean } \\
\text { value }\end{array}$ \\
\hline Unobtrusive & 21 & 6,29 & 3,149 &, 687 \\
\hline Anxious & 22 & 5,18 & 1,991 &, 560 \\
\hline depressive & 17 & 4,76 & 2,047 &, 497 \\
\hline
\end{tabular}

Table 13: Single factorial ANOVA.

\begin{tabular}{|c|c|c|c|c|c|c|}
\hline \multicolumn{2}{|c|}{} & Square sum & df & Means of Square & F & Significance \\
\hline \multirow{3}{*}{ Number of Incapacities } & Between the groups & 24,233 & 2 & 12,116 & 1,981 &, 147 \\
\cline { 2 - 7 } & Within the Groups & 348,617 & 57 & 6,116 & & \\
\cline { 2 - 7 } & Total & 372,850 & 59 & & & \\
\hline
\end{tabular}

Table 14: Multiple comparisons: Dependent variable: Number of Incapacities Scheffé- Procedure

\begin{tabular}{|c|c|c|c|c|c|c|}
\hline \multirow{2}{*}{ (I) Group } & \multirow{2}{*}{ (J) Group } & \multirow{2}{*}{$\begin{array}{c}\text { Mean difference } \\
(I-I)\end{array}$} & \multirow{2}{*}{ Std.-Error } & \multirow{2}{*}{ Sig. } & \multicolumn{2}{|c|}{ 95\% Confidenceinterval } \\
\hline & & & & & Lower Limit & Upper Limit \\
\hline \multirow{2}{*}{ Unobtrusive } & Anxious & 1,10 &, 754 & ,350 &,- 79 & 3,00 \\
\hline & Depressive & 1,52 & ,807 & ,178 &,- 51 & 3,55 \\
\hline \multirow{2}{*}{ Anxious } & Unobtrusive & $-1,10$ & ,754 & ,350 & $-3,00$ & ,79 \\
\hline & Depressive &, 42 & ,799 & ,873 & $-1,59$ & 2,42 \\
\hline \multirow{2}{*}{ Depressive } & Unobtrusive & $-1,52$ & 807 & 178 & $-3,55$ &, 51 \\
\hline & Anxious &,- 42 & 799 & ,873 & $-2,42$ & 1,59 \\
\hline
\end{tabular}

Basis: observed mean values.

The error term is mean of squares (error) $=6.116$. 
Due to the inferential static calculations there is no significant correlation between the independent variables (group membership) and the measured test cores of the dependent variables. The hypothesis $\mathrm{HO}$ is therefore to be rejected. Group membership is an important source of variance to explain the differences between the test values of the dependent variables. By calculating multiple comparisons (here: Scheffé), the varianceanalytical result can be specified to the effect that the groups differ significantly with respect to the naming of ability. This difference refers to the group of the inconspicuous to the anxious and depressive. It is highly significant at the 0.01 level. There is no significance between the groups of anxious and depressive persons. However, there is no significant difference between the different groups in the naming of inabilities. The hypothesis $\mathrm{H} 1$ is therefore only i.H. on the naming of the abilities to be rejected.

\section{Differentiation regarding the abilities}

According to hypothesis $\mathrm{H} 3$, it was tested whether significant differences in Quality of verbalized abilities or inabilities within and between groups. For this purpose, they were categorized according to physical (1st order), intellectual (2nd order) or social (3rd order) and the frequencies were checked for significance by calculating chi-square (Tables 14(a),15).

Table 14(a): Cross table: Group * Abilities.

\begin{tabular}{|c|c|c|c|c|c|c|}
\hline & & & 3rd order ability & $\begin{array}{l}\text { 2nd order } \\
\text { ability }\end{array}$ & $\begin{array}{c}\text { 1st order } \\
\text { ability }\end{array}$ & \\
\hline \multirow{9}{*}{ Group } & \multirow{3}{*}{ Unobtrusive } & Number & 3 & 12 & 6 & 21 \\
\hline & & Expected number & 7,4 & 11,2 & 2,4 & 21,0 \\
\hline & & Standardized recidual & $-1,6$ & ,2 & 2,3 & \\
\hline & \multirow{3}{*}{ Anxious } & Number & 14 & 8 & 0 & 22 \\
\hline & & Expected number & 7,7 & 11,7 & 2,6 & 22,0 \\
\hline & & Standardized recidual & 2,3 & $-1,1$ & $-1,6$ & \\
\hline & \multirow{3}{*}{ Depressive } & Number & 4 & 12 & 1 & 17 \\
\hline & & Expected number & 6,0 & 9,1 & 2,0 & 17,0 \\
\hline & & Standardized recidual &,- 8 & 1,0 &,- 7 & \\
\hline \multicolumn{2}{|r|}{ Total } & Number & 21 & 32 & 7 & 60 \\
\hline
\end{tabular}

Table 15: Chi-square tests.

\begin{tabular}{|c|c|c|c|}
\hline & Value & df & Asymptotic signifikance (two-sided) \\
\hline Chi-square after Pearson & $18,760^{\mathrm{a}}$ & 4 &, 001 \\
\hline Likelihood-quotient & 19,820 & 4 &, 001 \\
\hline Connection linear-with- linear & 3,039 & 1 & \\
\hline Number of value cases & 60 & & \\
\hline
\end{tabular}

a. 3 cells $(33,3 \%)$ have an expected frequency less than 5 , the minimum expected frequency is 1.98 .

According to this, there are significant differences in the quality of verbalized abilities or inabilities between and within groups. The verbalized abilities differ within the inconspicuous and the anxious groups see the standardized residuals. In the inconspicuous groups there is a significant difference between the actual number and the expected number of physical abilities
(St.R.2,3). The anxious verbalize more social skills than physical or intellectual skills in terms of actual numbers (St.R. 2,3). It is interesting to note that in the groups of the inconspicuous and depressive the social abilities of particularly few are mentioned. However, there is no significant difference in the expected number. Also interesting is the Information given by the depressives, who 


\section{Psychology and Behavioral Science International Journal}

name as many intellectual abilities as the inconspicuous. However, the difference between the number and the expected number is not a significant difference. The following picture emerges when compared with the inconspicuous abilities:

The hypothesis $\mathrm{H} 3$ can only be partially verified on the basis of these results (Tables 16 and 17).

Table 16: Cross table: Group * Inabilities.

\begin{tabular}{|c|c|c|c|c|c|c|}
\hline & Inab & rder. & & ilitie & & \\
\hline & & & $\begin{array}{l}\text { Inabilities } \\
\text { 3rd order. }\end{array}$ & & & Total \\
\hline & & Number & 9 & 12 & 0 & 21 \\
\hline & Unobtrusive & Expected number & 11,9 & 7,7 & 1,4 & 21,0 \\
\hline & & Standardized recidual &,- 8 & 1,5 & $-1,2$ & \\
\hline & & Number & 14 & 8 & 0 & 22 \\
\hline Group & Anxious & Expected number & 12,5 & 8,1 & 1,5 & 22,0 \\
\hline & & Standardized recidual & ,4 & 0 & $-1,2$ & \\
\hline & & Number & 11 & 2 & 4 & 17 \\
\hline & Depressive & Expected number & 9,6 & 6,2 & 1,1 & 17,0 \\
\hline & & Standardized & 4 & $-1,7$ & 2,7 & \\
\hline & Total & number & 34 & 22 & 4 & 60 \\
\hline
\end{tabular}

Table 17: Chi-Square-tests.

\begin{tabular}{|c|c|c|c|}
\hline & Value & df & Asymptotic signifikance (two-sided) \\
\hline Chi-square after Pearson & $16,484^{\mathrm{a}}$ & 4 &, 002 \\
\hline Likelihood-quotient & 17,197 & 4 & 1,002 \\
\hline Connection linear-with-linear &, 000 & 1 & \\
\hline Number of value cases & 60 & & \\
\hline
\end{tabular}

a 3 cells $(33,3 \%)$ have an expected frequency less than 5 , the minimum expected frequency is 1,13 .

The standardized residual of 2.7 in the depressed group shows a significant difference between the expected and actual number. In the verbalization of social incapacities (e.g. the lack of social contacts). This discrepancy in terms of inability to make social contacts is evident in the members of the groups of the inconspicuous or anxious more conspicuous, although not quite significant (as per margin -1.2, -1.2). Striking, although with a stand. R. below 2.0 is the difference in the number of answers in the expected and actual number of answers in the inconspicuous compared to the depressive in terms of verbalization of physical

Table 18: Duration of therapy.

\begin{tabular}{|c|c|c|c|}
\hline \multirow{3}{*}{ Therapy duration } & 1 & $\begin{array}{c}\text { few hours } \\
(<=25)\end{array}$ & 20 \\
\cline { 2 - 4 } & 2 & $\begin{array}{c}\text { many hours } \\
\text { (bis 60) }\end{array}$ & 12 \\
\cline { 2 - 4 } & 3 & $\begin{array}{c}\text { very many hours } \\
(>60)\end{array}$ & 13 \\
\hline
\end{tabular}

inabilities (1.5 and -1.7).

\section{Hypothesis 4}

With increasing duration of therapy and increased selfconfidence combined with an improved self-esteem, previously learned abilities are also verbalized more quickly again. In order to verify this, the abilities and inabilities mentioned above were variance-analyzed as a function of the duration of therapy. The following criteria were established for the duration of therapy (Tables 18 and 19). 


\section{Psychology and Behavioral Science International Journal}

Table 19: Tests of inter-subject effects.

\begin{tabular}{|c|c|c|c|c|c|c|}
\hline \multirow{2}{*}{ Source } & Dependent Variable & Square sum of type II & df & $\begin{array}{c}\text { Mean of the } \\
\text { squares }\end{array}$ & F & Sig. \\
\hline \multirow{2}{*}{ Corrected model } & Number of abilities & $905,927^{\mathrm{a}}$ & 4 & 226,482 & 9,220 &, 000 \\
\cline { 2 - 7 } & Number of inabilities & $82,264^{\mathrm{b}}$ & 4 & 20,566 & 3,893 &, 007 \\
\hline \multirow{2}{*}{ Therapy duration } & Number of abilities & 217,836 & 3 & 72,612 & 2,956 &, 040 \\
\cline { 2 - 7 } & Number of inabilities & 59,667 & 3 & 19,889 & 3,764 &, 016 \\
\hline
\end{tabular}

a. $\mathrm{R}$ square $=.401$ (corrected $\mathrm{R}$ square $=.358)$

b. $\mathrm{R}$ square $=.221($ corrected $\mathrm{R}$ square $=.164)$

Table 20: Multiple comparisons: Scheffé

\begin{tabular}{|c|c|c|c|c|c|c|c|}
\hline \multirow{2}{*}{ Dependent Variable } & \multirow{2}{*}{ (I) Group } & \multirow{2}{*}{ (J) Group } & \multirow{2}{*}{$\begin{array}{l}\text { Mean value diffe- } \\
\text { rence (I-J) }\end{array}$} & \multirow{2}{*}{ Std.-Error } & \multirow{2}{*}{ Sig. } & \multicolumn{2}{|c|}{ 95\% Confidenceintervall } \\
\hline & & & & & & Lower limit & Upper limit \\
\hline \multirow{6}{*}{$\begin{array}{l}\text { Number of } \\
\text { Abilities }\end{array}$} & \multirow{2}{*}{ Unobtrusive } & Anxious & $7,665^{*}$ & 1,510 & 000 & 3,87 & 11,46 \\
\hline & & Depressive & $8,266^{*}$ & 1,614 & 000 & 4,21 & 12,32 \\
\hline & \multirow{2}{*}{ Anxious } & Unobtrusive & $-7,665^{*}$ & 1,510 & 000 & $-11,46$ & $-3,87$ \\
\hline & & Depressive & 602 & 1,598 & ,932 & $-3,41$ & 4,62 \\
\hline & \multirow{2}{*}{ Depressive } & Unobtrusive & $-8,266^{*}$ & 1,614 & 000 & $-12,32$ & $-4,21$ \\
\hline & & Anxious & -602 & 1,598 & ,932 & $-4,62$ & 3,41 \\
\hline \multirow{6}{*}{ Number of Inabilities } & \multirow[b]{2}{*}{ Unobtrusive } & Anxious & 1,104 & ,754 & 350 &,- 79 & 3,00 \\
\hline & & Depressive & 1,521 & ,807 & 178 &,- 51 & 3,55 \\
\hline & \multirow{2}{*}{ Anxious } & Unobtrusive & $-1,104$ & ,754 & ,350 & $-3,00$ &, 79 \\
\hline & & Depressive & ,417 & ,799 & 873 & $-1,59$ & 2,42 \\
\hline & \multirow{2}{*}{ Depressive } & Unobtrusive & $-1,521$ & ,807 & , 178 & $-3,55$ &, 51 \\
\hline & & Anxious &,- 417 & ,799 & ,873 & $-2,42$ & 1,59 \\
\hline
\end{tabular}

${ }^{*}$ The mean value difference is significant at the 0.05 level.

Accordingly, the duration of therapy represents a significant source of variance, both for the number of abilities and the number of inabilities (Table 20).

\section{Interpretation of the test results of the empirical study}

With regard to the skills expressed, it can be stated that there is a significant difference between the individual groups studied. Especially between the groups of the inconspicuous and anxious, as well as in the comparison between the inconspicuous and depressive. This difference can be seen in a significantly higher number of verbalized abilities among the inconspicuous compared to the other two psychologically conspicuous groups.
The duration of therapy also has a significant influence on the naming of abilities and inabilities within the different groups. There is no measurable difference between the anxious and depressed groups. There is also a significant difference in the independent variable „number of inabilities“ between the different groups. There is no measurable difference between the anxious and the depressed. There is also a significant difference in the independent variable number of incapacities between the groups studied. A further difference lies in the quality of the answers. In the group of the inconspicuous it is noticeable that the actual number differs significantly from the expected number in terms of physical abilities. If they also, what the actual number 
are less verbalized. Intellectual abilities are named much more often than physical abilities. There is no difference compared to the depressive. In the group of anxious people, more social skills are named in comparison. The actual number here is significantly higher than expected. Striking but not explicitly significant is the number of social skills compared to the expected in the group of the inconspicuous.

The comparison with the inabilities shows the following picture: The standardized residue of 2.7 concerns the group of depressives mainly the verbalization of social inabilities (e.g. the lack of social contacts). In the case of this inability, however, there is a negative difference between the expected and the actual number of responses among the members of the groups of the inconspicuous or anxious in a conspicuous, though not entirely significant way (see R. -1.2, -1.2). Conspicuous, even if with a score. R. of not quite 2.0 is the number of inconspicuous in comparison with the depressive in terms of verbalization of physical inabilities (1.5 and -1.7, respectively). The assumption that there is a significant correlation between therapy success by increasing self-confidence and self-esteem on the reproductive ability of knowledge, skills and abilities could be proven by the results of the interference statistics. The significant difference between the inconspicuous and the other two therapy groups is particularly high, which can be explained by the fact that in the group of the inconspicuous there is no conspicuous limitation of the re-production of knowledge about one's own abilities, one's own skills, because in this group no pathological symptoms were present. There is no significant difference between the two therapy groups with regard to reproduction. However, there is a clear connection between a successful „denormalization“ and thus an improvement in the awareness of one's own abilities and corresponding skills.

\section{Summary}

Due to negative self-perception, lack of self-confidence and low self-esteem, anxious and depressive people are primarily concerned with what they cannot do, with their helplessness, their fears and depressions. As often described scientifically, these people internalize their failure and externalize experienced success in contrast to healthy people. Due to their internalized negative basic structure they are not able to accept positive experiences as their own contribution. It would create an inner chaos, a latent apperception-aversion-conflict. With such an inner conflict structure, the ability to make decisions per se would no longer exist. This threatening condition is prevented by this clientele, by attributing experienced success to coincidence or luck, failure however on own inability and personal failure.

An inhibition of the ability to remember, independent of the respective psychopathological symptoms, naturally lies in the area of forgetting. However, it is important to point out that, in addition to the scientific knowledge about forgetting, a simple fact, such as normalization, or the explanation as a matter of course of learned abilities and skills, reduces the ability to remember. This is because everything that is normal or taken for granted is no longer special and therefore does not deserve any reward (reinforcement) and is therefore deleted in the long term. In contrast to this it is the case with the inabilities, they are perceived as disturbing and stressful and are kept in consciousness by the emotional negative character and thus not forgotten. The results of this examination can be of particular interest for psychotherapeutic action. As patients learn to become aware of their acquired abilities again, to no longer take even the smallest and simplest ones for granted and call them something normal, but to regard and interpret them as something very personal, sometimes under pain, acquired abilities (e.g. running), and to evaluate them accordingly positively, even if not as strongly as at the beginning of the acquisition, a reciprocal inhibition of forgetting occurs due to this strengthening of these abilities. In addition, through the awareness or de-normalization of the abilities and the rediscovered knowledge about them, the self-confidence in dealing with these abilities increases, which ultimately leads to the development of improved problem-solving strategies and thus will substantially increase and stabilize the patient's self-esteem.

\section{References}

1. Baumeister RF (1998) The self. In: DT Gilbert, ST Fiske, G Lindzey (Eds.) The handbook of social psychology ( $4^{\text {th }}$ Edtn) Mc Graw, New York, United States pp.680-740.

2. James W (1890) The principles of psychology. Holt, New York, United States.

3. Cooley Ch H (1956) Social Organization. Human Nature and Social Order. Free Press, Glencoe Illinois, New York, United States.

4. Mead GH (1968) Geist, Identität und Gesellschaft. Frankfurt a. Main: Suhrkamp, Germany.

5. Längle A (2002) Sinnvoll Leben, Freiburg im Breisgau: Herder Verlag, Germany.

6. Waibel EM (1994) Erziehungzum Selbstwert. Persönlichkeitsförderung als zentrales pädagogisches Anliegen. Auer-Verlag, Donauwörth, Germany.

7. Shavelson RJ, Hubner JJ, Stanton G.C (1976) Self-concept: Validation of construct interpretation. Review of educational research 46: 407-441.

8. Filipp SH, Frey D (1988) Das Selbst. In: K Immelmann, KR Scherer C Vogel, P Schmoock (Hrsg.), Psychobiologie. Grundlagen des Verhaltens. Gustav Fischer Verlag, Stuttgart, Germany S.415-454.

9. Marsh HW, Byrne BM, Shavelson RJ (1992) A multidimensional, hierarchical self- concept. In: TM Brinthaupt, RP Lipka (Eds.), SUNY series, studying the self. The self: Definitional and methodological issues State University of New York Press, United States p.44-95.

10.Schütz A (2003) Psychologie des Selbstwertgefühls: Von Selbstakzeptanz bis Arroganz. In: Kohlhammer aktualisierte Auflage, W Druckerei GmbH, Stuttgart, Germany.

11. Skinner BF (1974) Die Funktion der Verstärkung. In: der Verhaltenswissenschaft. Kindler Verlag, München, Germany.

12. Thorndike EL (1898) Animal intelligence: An experimental study of the associative processes in animals. Psychological Monographs: General and Applied 2(4): i-109. 
13. Squire R, Knowlton BJ, Musen G (1993) The structure and organization of memory. Annual Review of Psychology 44: 453-495.

14. Ebbinghaus, H (1885) Über das Gedächtnis: Untersuchungen zur experimentellen Psychologie. Duncker \& Humblot, Leipzig, Germany.

15. Linton M (1986) Ways of searching and the contents of memory'. In: Rubin DC (ed.) Autobiographical Memory, Cambridge, England.

16. Dimbath 0, Heinlein M (Hrsg.) (2014) Die Sozialität des Erinnerns, Soziales Gedächtnis, Erinnern und Vergessen - Memory Studies, Springer Fachmedien, Wiesbaden, Germany.

17. Esposito E (2002) Soziales Vergessen - Formen und Medien des Gedächtnisses der Gesellschaft. Suhrkamp Taschenbuch-Verlag, Berlin, Germany.

18. Kara S, Die Zeit Nr (2015) Gedächtnis: Vergiss es! Sie haben ein löchriges Gedächtnis? Hervorragend! Vergessen befreit, hält die Liebe frisch und die Gesellschaft zusammen.
19. Draaisma D (2012) Das Buch des Vergessens: Warum Träume so schnell verloren gehen und Erinnerungen sich ständig verändern. Verlag Kiepenheuer \& Witsch, Cologne, Germany.

20. Beck AT, Epstein N, Brown G, Steer RA (1988) An inventory for measuring clinical anxiety: Psychometric properties. Journal of Consulting and Clinical Psychology. 56: 893-897.

21. Beck AT, Ward CH, Mendelson M, Mock J, Erbaugh J (1961) An inventory for measuring depression. Arch Gen Psychiatry 4: 561-571.

22. Deutsche Ausgabe herausgegeben von P. Falkai und H.-U. Wittchen, Mitherausgegeben von M. Döpfner, W Gaebel, W Maier, W Rief, et al. (2018) Diagnostisches und Statistisches Manual Psychischer Störungen DSM-5 ${ }^{\circledR}$, Deutsche Übersetzung, Hogrefe Verlag, Berlin, Germany.

23. Dilling H, Mombour W, Schmidt MH (1993) Klassifikation psychischer Krankheiten. Lehrbuch der Verhaltenstherapie, Huber, Bern, United States pp.181-200.

\section{Your next submission with Juniper Publishers will reach you the below assets}

- Quality Editorial service

- Swift Peer Review

- Reprints availability

- E-prints Service

- Manuscript Podcast for convenient understanding

- Global attainment for your research

- Manuscript accessibility in different formats

( Pdf, E-pub, Full Text, Audio)

- Unceasing customer service

Track the below URL for one-step submission https://juniperpublishers.com/online-submission.php 